\title{
PENERAPAN THRESHOLD DALAM PEMILU MENURUT PERSPEKTIF GUSTAV RADBRUCH DAN HANS KELSEN
}

\author{
Sholahuddin Al-Fatih ${ }^{1 *}$ \\ 1*Fakultas Hukum, Universitas Muhamamdiyah Malang, Indonesia, sholahuddin.alfath@gmail.com \\ (corresponding)
}

\begin{abstract}
This study tries to discuss the tensions that occur between legal experts in formulating basic values that become the right legal objectives. Figures that are used as a comparison in the perspective of this legal objective are Gustav Radbruch and Hans Kelsen. Through a conceptual and case approach, this study tries to examine the concept of law based on contextual cases that occur in society, namely the application of the threshold in elections. In this study, the application of the threshold in elections is used as a measuring tool to determine legal objectives as stated by Gustav Radbruch and Hans Kelsen. The results of this study indicate that Gustav Radbruch sees and tends to the value of justice as a legal goal, like what Hans Kelsen found. The difference between Gustav Radburch's justice and Hans Kelsen lies in how to measure and realize this justice. This research is expected to be able to help academics and legal practitioners to dig deeper into the philosophical objectives of law in order to create laws that can answer the needs of society.
\end{abstract}

Keywords: Threshold; Gustav Radbruch; Hans Kelsen

\section{PENDAHULUAN}

Sesuatu diciptakan untuk memiliki tujuan. Manusia misalnya, dalam konteks manusia diciptakan bertujuan untuk beribadah kepada Tuhan (Sada, 2016). Begitu pula dengan hukum. Hukum diciptakan dengan tujuan tertentu (Shidiq, 2009). Melihat pada beberapa nilai-nilai dasar hukum, para pakar mengemukakan tentang tujuan hukum, diantaranya untuk keadilan, kemanfaatan dan kepastian. Perdebatan para pakar hukum tidak hanya berputar pada ketiga nilai dasar atau tujuan hukum tersebut saja, namun juga secara filosofis melihat dari makna hukum itu sendiri.

Ketegangan antara nilai dasar hukum yang meliputi 3 hal tersebut seringkali ditemukan dalam kehidupan berbangsa dan bernegara. Dalam konteks
Indonesia hari ini misalnya, di saat pandemi Covid-19 sedang berlangsung dan grafik penambahan kasus positif di Indonesia belum turun (Zubaidi, Pratamab, \& Al-Fatih, 2020). Pemerintah justru tetap mengambil sikap untuk menyelenggarakan Pilkada Serentak pada bulan Desember mendatang (Rizki \& Hilman, 2020). Hal ini tentu menjadi anomali yang bisa menimbulkan ketegangan antara para pakar dalam menentukan nilai dasar hukum yang harus diambil dalam situasi seperti ini.

Setelah sempat terjadi diskusi di beragam forum mengenai kelanjutan Pilkada serentak di tahun 2020 ini, pemerintah telah mencoba memberikan kepastian hukum melalui Perppu Nomor 2 Tahun 2020 (Kennedy \& Suhendarto, 2020). Dalam Pasal 201 A ayat (2) Perppu Nomor 2 Tahun 2020 disebutkan bahwa Pilkada serentak diselenggarakan pada bulan 
Desember mendatang. Hal ini sekaligus menjadi jawaban dan memberikan kepastian hukum bagi penyelenggara, calon maupun masyarakat, yang sempat meragukan kelanjutan Pilkada yang awalnya terjadwal diselenggarakan pada bulan September.

Kepastian hukum terkait jadwal pelaksanaa Pilkada serentak tahun 2020 juga semakin dikuatkan dengan beberapa peraturan serta dokumen terkait. Sebut saja adanya surat dari Ketua Gugus Tugas Penanganan Covid-19 Nomor B196/KAGUGAS/PD.01.02/05/2020 kepada Ketua KPU tertanggal 27 Mei 2020. Surat tersebut memberikan amanah agar tahapan Pilkada kembali dilanjutkan asalkan tetap memenuhi protokol kesehatan. Selain itu, terdapat fakta bahwa pemerintah pusat telah mencairkan sekitar 50-80\% NPHD kepada penyelenggara Pilkada di daerah. Artinya, dana untuk penyelenggaraan Pilkada sudah didistribusikan, sehingga apabila Pilkada ditunda, rawan menimbulkan dampak yang justru lebih berbahaya. Lebih dari itu, tidak ada satupun ilmuwan atau pusat data yang bisa menjamin kapan berakhirnya pandemi Covid-19 ini, baik secara global maupun nasional.

Meskipun demikian, kita juga tidak bisa menutup mata dari fakta bahwa pandemi Covid-19 ini belum berakhir, bahkan cenderung grafik harian kasus positif Covid-19 yang terkonfirmasi meningkat. Secara global, berdasarkan laman Worldometer per 30 September 2020, terdapat 34.111.625 kasus positif, 1.017.406 meninggal dan 25.332.836 sembuh (Worldometer, 2020). Jumlah tersebut juga meliputi total kasusu yang terjadi di Indonesia sebanyak 287.008 kasus posiitf, 10.740 meninggal dunia dan 214.947 sembuh (Worldometer, 2020). Secara umum, grafik angka positif Covid-19 di Indonesia, terus meningkat. Sehingga, apabila Pilkada tetap dipaksakan diselenggarakan pada bulan Desember mendatangkan, dikhawatirkan bisa memunculkan klaster baru transmisi Covid-19.

Dalam konteks tersebut, tujuan hukum kemanfaatan harus lebih dilihat dibandingkan kepastian hukum. Sebab, nyawa manusia tentu lebih berharga daripada kontestasi pengisian jabatan bernama Pilkada. Para pakar juga telah memberikan pendapatnya mengenai penundaan Pilkada yang seharusnya menjadi solusi utama di kala pandemi Covid-19 ini (Hasibuan, 2020). Sehingga, dalam konteks Pilkada di tengah pandemi Covid-19 ini saja, terdapat ketegangan antara para pakar dalam merumuskan tujuan hukum mana yang dipilih untuk menyikapi dinamika kehidupan berbangsa dan bernegara yang terjadi.

Selain terkait penyelenggaraan Pilkada di tengah pandemi Covid-19, ketegangan nilai dasar tujuan hukum juga bisa dilihat dari penerapan threshold dalam pemilu. Sejak pertama kali diterapkan pada pemilu tahun 2004, threshold (baik istilah electoral threshold, parliamentary threshold maupun presidential threshold), telah memunculkan pro dan kontra (AlFatih, 2019).

Pendapat yang menyetujui penerapan threshold beralasan bahwa threshold memberikan kepastian hukum. Sementara pendapat kontra beralasan bahwa penerapan threshold justru tidak memenuhi nilai-nilai keadilan sesuai dengan tujuan hukum. Sebab, threshold, baik parliamentary threshold maupun presidential threshold secara matematis dan normatif membatasi hak seseorang untuk terpilih dan dipilih dalam kontestasi pemilu. Lebih dari itu, pro dan kontra penerapan threshold juga memunculkan sudut pandang baru berkaitan dengan perhitungan secara matematis besaran threshold tersebut (Fatih, 2018).

Beberapa penelitian terdahulu yang menjadi titik tolak dan perbandingan cara berpikir berkaitan dengan gagasan Gustav Radbruch dan Hans Kelsen, diantaranya: 1) Frank Haldemann dengan judul penelitian Gustav Radbruch vs Hans Kelsen: A Debate on Nazi Law pada tahun 2005 (Haldemann, 2005). Penelitian Frank Haldemann menjadikan hukum Nazi sebagai obyek utama dan berfokus pada hukum di Jerman. 2) Klaus Adomeit dengan judul Der Rechtpositivismus im Denekn von Hans Kelsen und von Gustav Radbruch pada tahun 2003 (Adomeit, 2003). Penelitian tersebut secara umum membahas cara berpikir hukum positif yang ditawarkan oleh Hans Kelsen dan Gustav Radbruch.

3) Douglas G. Morris dengan judul penelitian Accommodating Nazi Tyranny? The Wrong Turn of the Social Democratic Legal Philosopher Gustav Radbruch After the War pada tahun 2016 (G. Morris, 2016). Penelitian tersebut membahas beberapa kesalahan cara berpikir Gustav Radbruch dan Hans Kelsen. Dari beberapa penelitian yang secara vis a vis menjadikan pemikiran Gustav Radbruch dan Hans Kelsen sebagai sebuah perbandingan cara berpikir, belum ada penelitian terdahulu yang membahasnya dengan menggunakan threshold sebagai obyek spesifik penelitian. Sehingga, penelitian ini merupakan penelitian yang otentik dan bisa bermanfaat bagi khazanah keilmuan hukum. 


\section{Sholahuddin Al-Fatih \\ pp. $78-84$}

E-ISSN : 2723-2476

ISSN : 2723-1968

ACLJ, Vol. 1, Issue 2, 2020
Perdebatan dan ketegangan dalam menentukan nilai dasar tujuan hukum meang menjadi sebuah hal sepertinya tidak ada batasnya. Sehingga, bahan kajian dengan topik tersebut akan selalu menjadi topik penelitian maupun diskusi yang selalu menarik utnuk ditemukan jalan tengahnya. Melalui penerapan threshold, penulis mencoba mengkaji pemikiran Gustav Radbruch dan Hans Kelsen mengenai tujuan hukum.

\section{METODE PENELITIAN}

Penelitian ini adalah jenis penelitian hukum dengan pendekatan konseptual (conceptual approach) (Peter Mahmud Marzuki, 2014). Penelitian hukum merupakan suatu penelitian yang mengkaji norma, berkaitan dengan tumpang tindih, kekosongan maupun kekaburan norma yang ada. Norma yang coba dikaji dalam penelitian ini adalah berkaitan dengan tujuan hukum.

Konsep yang digunakan sebagai alat ukur adalah konsep threshold yang diterapkan dalam pemilu di Indonesia. Melalui analisis preskriptif (Peter Mahmud Marzuki, 2017), penulis mencoba menemukan argumentasi baru berkaitan dengan tujuan hukum yang dikemukakan oleh Gustav Radbruch dan Hans Kelsen

\section{HASIL DAN PEMBAHASAN}

\section{Threshold dalam Pemilu}

Threshold mulai diterapkan sejak pemilu tahun 2004. Threshold diartikan sebagai batasan. Dalam pemilu, threshold digunakan untuk membatasi para kandidat, baik sebelum kontestasi pemilu berlangsung maupun setelah hasil pemilu diumumkan. Di Indonesia, terminologi mengenai threshold dikenal dalam 3 istilah, yaitu electoral threshold, parliamentary threshold dan presidential threshold. Kini, hanya dua istilah threshold terakhir yang digunakan, yaitu parliamentary dan presidential threshold.

Parliamentary threshold digunakan sebagai cara untuk membatasi jumlah partai politik peserta pemilu untuk bisa mengirimkan wakilnya ke parlemen di DPR. Sebagai gambaran misalnya, Partai Solidaritas Indonesia atau PSI pada pemilu 2019 lalu gagal mengirimkan wakilnya ke DPR karena suara yang diperoleh oleh PSI dalam pemilu legislatif dibawah ambang batas parlemen yang telah ditentukan yaitu sebesar 4\%. Tidak cuma PSI, beberapa partai peserta pemilu lainnya seperti Partai Perindo, PBB, Partai Garuda, PKPI, Hanura dan Partai Berkarya juga gagal lolos ke parlemen karena ketentuan mengenai parliamentary threshold tersebut (Kompas, 2019).
Besaran parliamentary threshold dari tahun ke tahun selalu meningkat (Al-Fatih, 2019). Pada awal ditetapkannya, parliamentary threshold hanya sebesar 2,5\%. Besaran parliamentary threshold kemudian naik pada periode berikutnya menjadi 3,5\%. Bahkan pada pemilu terakhir tahun 2019 lalu, besraan parliamentary threshold naik menjadi $4 \%$. Secara matematis, dalam Undang-Undang Nomor 7 Tahun 2017 tentang Pemilu, tidak disebutkan dari mana besaran parliamentary threshold tersebut diperoleh. Keadaan ini kemudian memunculkan pertanyaan besar, apakah mungkin parliamentary threshold menjadi alat transaksi politik dan kesepakatan para elit partai di parlemen. Sebab, tren menaikkan besaran parliamentary threshold secara faktual menguntungkan partai-partai besar dengan suara yang stabil.

Kejadian serupa juga terjadi dalam penentuan besaran presidential threshold. Dalam dua periode pemilu presiden atau pilpres terakhir, hanya ada 2 kelompok yang bisa ikut berkontestasi dalam pilpres, yaitu PDI-P dan Gerindra. Calon yang mereka jagokan juga sama, yakni antara Joko Widodo dengan Prabowo Subianto. Polarisasi dukungan ini sebenarnya merupakan dampak dari penerapan kebijakan terkait presidential threshold sebesar 20\%. Besaran presidential threshold tersebut secara tidak langsung mereduksi hak berpolitik masyarakat Indonesia.

Angka 20\% juga masih menjadi perdebatan, bahkan beberapa kali dilakukan judicial review ke Mahkamah Konstitusi. Terakhir, besaran presidential threshold 20\% digugat oleh Rizal Ramli (Saputra, 2020). Rizal Ramli menginginkan agar presidential threshold dihapus karena tidak konstitusional dan melanggar hak berpolitik masyarakat. Gugatan Rizal Ramli tersebut saat ini masih dibahas dalam Rapat Permusyawaratan Hakim (RPH).

Banyaknya angka judicial review terkait threshold tersebut, sejatinya mengindikasikan bahwa nilai dasar norma yang berkaitan dengan threshold masih sangat terbuka untuk diperbdebatkan. Seperti yang penulis jelaskan di bagian pendahuluan, mereka yang menyetujui penerapan threshold berlandaskan pada tujuan kepastian hukum. Hukum harus mampu memberikan kepastian. Threshold dijadikan sebagai alat untuk membatasi hak berpolitik secara konstitusional. Sebab, beberapa kali pula Mahkamah Konstitusi mendalilkan bahwa sifat threshold adalah konstitusional.

Di lain sisi, sudah banyak korban threshold dalam pemilu kita. Misalnya saja beberapa partai yang tadi disebutkan, seperti PSI, Partai Perindo, PBB, Partai Garuda, PKPI, Hanura dan Partai Berkarya. Jauh 
sebelum mereka, beberapa partai tercatat gagal bersaing karena threshold, seperti Partai Damai Sejahtera (PDS) yang notabene merupakan representasi dari umat kristiani, Partai Keadilan yang kemudian berubah nama menjadi Partai Keadilan Sejahtera, juga karena gagal memenuhi ambang batas parlemen saat itu. Dalam konteks pilpres, lebih banyak lagi kandidat yang gagal melaju dalam kontestasi pilpres karena terhalang besaran presidential threshold. Misalnya dalam pilpres tahun 2019 lalu, ada nama Gatot Nurmantyo, Agus Harimurti Yudhoyono, Muhaimin Iskandar dan banyak lagi.

Keadaan ini menjadikan threshold seperti buah simalakama. Bagi mereka yang kontra terhadap penerapan threshold, tentu saja threshold tidak bisa memenuhi tujuan hukum, yaitu keadilan. Selain keadilan, sangat mungkin juga terbuka peluang bahwa penerapan threshold gagal memenuhi tujuan hukum yang lain, yaitu kemanfaatan. Sebab, dengan direduksinya hak berpolitik masyarakat, maka manfaat yang didapatkan juga akan berkurang. Misalnya, dengan gagalnya PDS berkembang dan melaju ke parlemen, maka hak-hak umat kristiani agak susah untuk diperjuangkan. Atau dalam kasus pilpres, dengan gagalya beberapa kandidat untuk mencalonkan diri, maka masyarakat hanya bisa memilih calon itu-itu saja. Secara teoritis dan empiris, kondisi ini tentu bukan merupakan gambaran yang ideal bagi negara demokrasi modern.

\section{Perbandingan Tujuan Hukum Menurut Gustav Radbruch dan Hans Kelsen}

Perbedaan atau ketegangan antara nilai hukum sangat biasa dan mungkin terjadi. Dua tokoh yang pemikirannya bisa dijadikan sebagai perbandingan terkait konsep tujuan hukum adalah Gustav Radbruch dan Hans Kelsen. Gagasan yang dikembangkan oleh keduanya seringpula dijadikan sebagai rujukan oleh para akademisi dan praktiis dalam memahami hukum, tak terkecuali di Indonesia. Sehingga, akan menarik jika perdebatan mengenai tujuan hukum mengambil gagasan serta filsoofi yang dikembangkan oleh kedua tokoh tersebut.

Gustav Radbruch (1878-1949) merupakan filsuf hukum berkebangsaan Jerman (Bodenheimer, 1981). Pemikiran dan gagasan-gagasan Radburch sangat kuat dipengaruhi oleh Perang Dunia Kedua dan Nazi-Hitler di Jerman (Spaak, 2009). Radbruch mengatakan bahwa hukum merupakan aturan umum yang digunakan untuk mengatur kehidupan bersama dalam masyarakat. Tujuan utama dari hukum adalah untuk menciptakan keadilan (Bodenheimer, 1981)(Syafrida. Hartati, 2019)(Radbruch, Paulson, Paulson, Radbruch, \& Paulson, 2014). Tetapi Radburch juga meyakini bahwa keadilan adalah konsep yang bias dan tidak dapat ditentukan secara mutlak/tidak dapat diukur. Untuk bisa merumuskan keadilan secara spesifik, Radburch menambahkan adanya gagasan penting mengenai kebijaksanaan. Kebijaksanaan dianggap sebagai salah satu tolok ukur yang bisa menentukan seseorang untuk berbuat dan berlaku adil atau tidak.

Radbruch menambahkan bahwa tatanan hukum tidak bisa dijadikan sebagai mainan antara pendapat politik dan sosial yang saling bertentangan. Sehingga, melihat hukum dari aspek keadilan dan kebijaksanaan saja tidaklah cukup, maka diperlukan kepastian hukum. Kepastian hukum tersebut menuntut pengesahan dan pemeliharaan tatanan hukum yang positif dan mengikat oleh negara (Bodenheimer, 1981). Dari penjelasan Radbruch tersebut, bisa kita tarik benang merah bahwa Radbruch mencoba untuk membuat klasifikasi atau tingkatan tujuan hukum, mulai dari keadilan,(Michael, 2018) kebijaksanaan atau kemanfaatan dan kepastian hukum. Meskipun demikian, Radbruch mencoba mengelaborasikan ketiga nilai hukum tersebut sesuai dengan kebutuhan dalam waktu tertentu.(Muslih, 2013) Nilai-nilai dasar tersebut yang kelak menjadi landasan berpikir bagi penalaran hukum untuk menghasilkan produk hukum.(Setiawan, 2017)(Julyano \& Sulistyawan, 2019)

Sementara itu, Hans Kelsen mengawali pandangannya tentang tujuan hukum dengan menyebut bahwa hukum merupakan tatanan perilaku manusia.(Kelsen, 1949) Kelsen juga berpendapat bahwa kecenderungan untuk mengidentifikasi hukum dan keadilan adalah kecenderungan untuk membenarkan tatanan sosial tertentu. Pendapat tersebut tentu bukanlah sebuah pendapat atau gagasan ilmiah, melainkan pendapat yang bersifat politis. Sehingga pernyataan tersebut bisa berubah menjadi pertanyaan yang jawabannya juga sulit untuk ditebak kebenarannya. Oleh karenanya, sejak manusia terbagi menjadi beragam bangsa, agama, suku, ras, bahasa, profesi dan sebagainya, maka sejak saat itu pula sangat sulit mendeskripsikan makna hukum dan keadilan itu sendiri.

Sebagai penengah, Kelsen mengaggas ide baru tentang nilai dasar hukum yang dilandaskan pada gabungan antara nilai hukum alam dan nilai hukum positifistik atau empiris. Kelsen menyebutnya sebagai hukum murni.(Wardiono \& Dimyati, 2014) Dalam hukum murni, Kelsen mengukur keadilan melalui 


\section{Sholahuddin Al-Fatih \\ pp. $78-84$}

E-ISSN : 2723-2476

ISSN : 2723-1968

ACLJ, Vol. 1, Issue 2, 2020 sejauh mana suatu aturan itu diterapkan dan ditegakkan.(Rizhan, 2020) Secara umum, ada tiga pokok pemikiran Kelsen yang melandasi lahirnya gagasan ilmu hukum murni beserta nilai-nilainya, yaitu:(Samekto, 2012) hukum harus dilepaskan dari pertimbangan di luar hukum (termasuk moral, politis, ekonomi dan sebagainya), hukum harus benar-benar objektif tanpa prasangka, dan keadilan adalah persoalan di wilayah ought to be (yang seharusnya) bukan is (yang ada).

Berdasarkan penjelasan tersebut, secara garis besar gagasan Kelsen ini bertentengan dengan pendapat John Austin, Lon Fueller maupun Hart. Dapat pula ditarik benang merah, meskipun Kelsen menekankan bahwa niali hukum adalah keadilan, tapi titik tekannya adalah nilai positifistik berdasarkan kepastian hukum. Sehingga, argumen Kelsen menyoal keadilan adalah keadilan subyektif yang didasarkan pada upaya pemenuhan hukum positif.(Mukhlishin \& Sarip, 2020) Hal ini juga selaras dengan pernyataan Kelsen yang mengatakan bahwa tolok ukur keadilan adalah dipenuhinya sebuah aturan atau tidak.

Ketegangan nilai hukum yang dikemukakan oleh Radbruch maupun Kelsen tersebut juga nampak secara nyata dalam pembentukan norma terkait threshold, baik dalam Pemilu Legislatif ataupun Pemilu Presiden. Sejak pertama kali diperkenalkan dalam pemilu tahun 2004 hingga tahun 2019, belum ada satupun norma yang secara tegas mengatur secara sistematis rumus tentang penentuan besara threshold, baik Parliamentary Threshold maupun Presidential Threshold (Al-Fatih, 2019). Sehingga, dalam perspektif Radbruch maupun Kelsen, ketiadaan norma yang pasti tentang rumusan threshold tersebut, membuat hukum tidak bisa memenuhi nilai keadilan, kemanfaatan maupun tidak berkepastian hukum.

\section{PENUTUP}

Sebagai penutup, berdasarkan uraian tersebut diatas dapat disimpulkan bahwa Gustav Radburch menilai hukum berdasarkan keadilan secara subyektif melihat pada kondisi diberlakukannya hukum dan tetap mengelaborasi nilai-nilai kemanfaatan dan kepastian hukum. Sementara Hans Kelsen menilai hukum berdasarkan keadilan secara subyektif berdasarkan pemenuhan atas aturan yang berlaku atau hukum positif atau lebih ditekankan kepada nilai kepastian hukum. Beritik tolak pada kedua gagasan Radbruch dan Kelsen tersebut, maka sampai detik ini Pemerintah tidak bisa menjamin keadilan, kemanfaatan maupun kepastian hukum berkaitan dengan penerapan threshold di Indonesia.

\section{Daftar Pustaka}

Adomeit, K. (2003). Der Rechtpositivismus im Denekn von Hans Kelsen und von Gustav Radbruch. Juristen Zeitung, 58(4), 161-166.

Al-Fatih, S. (2019). Akibat Hukum Regulasi tentang Threshold dalamPemilihan Umum Legislatif dan Pemilihan Presiden: Kajian Putusan Mahkamah Konstitusi Nomor 52/PUU-X/2012 dan Nomor 14/PUU-XI/2013. Jurnal Yudisial, 12(1), 17-38. https://doi.org/10.29123/jy.v12i1.258

Bodenheimer, E. (1981). Jurisprudence: The Philosophy and Method of Law. In Tesis Ricardo (Fourth Edi, Vol. 53). https://doi.org/10.1017/CBO9781107415324.00 4

Fatih, S. Al. (2018). Implementasi Parliamentary Threshold Dalam Pemilihan Anggota Dprd Provinsi Dan Dprd Kabupaten/Kota. Ahkam: Jurnal Hukum Islam, 6(2). https://doi.org/10.21274/ahkam.2018.6.2.363388

G. Morris, D. (2016). Accommodating Nazi Tyranny? The Wrong Turn of the Social Democratic Legal Philosopher Gustav Radbruch After the War. Law and History Review, 34(3), 649-688.

Haldemann, F. (2005). Gustav Radbruch vs Hans Kelsen: A Debate on Nazi Law. Ratio Juris, 18(2). https://doi.org/https://doi.org/10.1111/j.14679337.2005.00293.x

Hasibuan, R. P. P. M. (2020). Urgensitas Perppu Pilkada di Kala Wabah pandemi Covid-19. Adalah: Buletin Hukum Dan KeadilanAdalah, 4(1), 121-128. https://doi.org/10.15408/adalah.v4i1.15503

Julyano, M., \& Sulistyawan, A. Y. (2019). Pemahaman Terhadap Asas Kepastian Hukum Melalui Konstruksi Penalaran Positivisme Hukum. Jurnal Crepido, 01(01), 13-22. https://doi.org/https://ejournal2.undip.ac.id/index .php/crepido/article/download/6325/3197

Kelsen, H. (1949). General theory of Law and State. [Teoría general del Derecho y del Estado]. 
Kennedy, R., \& Suhendarto, B. P. (2020). Diskursus Hukum: Alternatif Pola Pengisian Jabatan Kepala Daerah di Masa Pandemi Covid-19. Jurnal Pembangunan Hukum Indonesia, 2(2), 188-204. https://doi.org/10.14710/jphi.v2i2.188-205

Kompas. (2019). Penetapan KPU: 9 Parpol Lolos Parlemen.

Michael, T. (2018). Pergerakan Fakultas Hukum Dalam Dimensi tri Dharma (Modernitas Dan Ortodoks). Prosiding Call For Paper Dan Pengabdian Masyarakat Dalam Rangka Dies Natalis Ke-60 Universitas 17 Agustus 1945 Surabaya, 6.

Mukhlishin \& Sarip. (2020). KEADILAN DAN KEPASTIAN HUKUM : MENYOAL KONSEP KEADILAN HUKUM HANS KELSEN PERSPEKTIF "AL-,ADL” DALAM ALQUR'AN. Media Keadilan : Jurnal Ilmu Hukum, 11(1).

https://doi.org/https://doi.org/10.31764/jmk

Muslih, M. (2013). Negara Hukum Indonesia dalam Perspektif Teori Hukum Gustav Radbruch. Legalitas, 4(1), 130-152.

Peter Mahmud Marzuki. (2014). Penelitian Hukum. Jakarta: Kencana Prenada Media Group.

Peter Mahmud Marzuki. (2017). Penelitian Hukum: Edisi Revisi (Cetakan ke). Retrieved from https://books.google.co.id/books?id=CKZADwA AQBAJ\&printsec $=$ frontcover\&dq=Marzuki, + Pet er+Mahmud,+(2014),+Penelitian+Hukum,+Ceta kan+ke-

9,+Jakarta:+Kencana+Media+Group.\&hl=id\&sa $=$ X\&ved=0ahUKEwiNlIjqlbTpAhXWWisKHW ktCXAQ6AEIMjAB\#v=onepage $\& q \& \mathrm{f}=$ false

Radbruch, G., Paulson, B. L., Paulson, S. L., Radbruch, G., \& Paulson, S. L. (2014). Five Minutes of Legal Philosophy. Oxford Journals of Legal Studies, 26(1), 13-15.

Rizhan, A. (2020). KONSEP HUKUM DAN IDE KEADILAN BERDASARKAN TEORI HUKUM STATIS (NOMOSTATICS) HANS KELSEN. KODIFIKASI, 2(1), 61-71. Retrieved from

http://ejournal.uniks.ac.id/index.php/KODIFIKA SI/article/view/679
Rizki, S. C., \& Hilman, Y. A. (2020). Menakar Perbedaan Opini Dalam Agenda Pelaksanaan Kontestasi Pilkada Serentak Di Tengah Covid-19. Jurnal Ilmiah Muqoddimah: Jurnal Ilmu Sosial, Politik Dan Humaniora, 4(2), 143-155. Retrieved from http://jurnal.umtapsel.ac.id/index.php/muqoddimah/article/view/ 1709/996

Sada, H. J. (2016). MANUSIA DALAM PERSPSEKTIF AGAMA ISLAM. AlTadzkiyyah : Jurnal Pendidikan Islam, 7(1), 129142.

https://doi.org/10.1017/CBO9781107415324.00 4

Samekto, Fxa. (2012). Menggugat Relasi Filsafat Positivisme Dengan Ajaran Hukum Doktrinal. Jurnal Dinamika Hukum, 12(1), 74-84. https://doi.org/10.20884/1.jdh.2012.12.1.108

Saputra, A. (2020). MK Bawa Nasib Gugatan Rizal Ramli soal Presidential Threshold ke RPH.

Setiawan, A. (2017). Penalaran Hukum Yang Mampu Mewujudkan Tujuan Hukum Secara Proporsional. Jurnal Hukum Mimbar Justitia, 3(2), 204. https://doi.org/10.35194/jhmj.v3i2.257

Shidiq, G. (2009). TEORI MAQASHID ALSYARI'AH DALAM HUKUM ISLAM. Majalah Ilmiah Sultan Agung, 44(118). https://doi.org/10.1001/archneur.58.4.677

Spaak, T. (2009). Meta-ethics and legal theory: The case of gustav radbruch. Law and Philosophy, 28(3), 261-290. https://doi.org/10.1007/s10982008-9036-8

Syafrida. Hartati, R. (2019). MEWUJUDKAN PERLINDUNGAN HUKUM DAN JAMINAN KEPASTIAN HAK KONSUMEN MUSLIM TERHADAP PRODUK HALAL (SUATU KAJIAN AJARAN GUSTAV RADBRUCH). Jurnal Hukum Replik, 7(1), 38-54. https://doi.org/10.1017/CBO9781107415324.00 4

Wardiono, K., \& Dimyati, K. (2014). Basis Epistemologis Paradigma Rasional Dalam Ilmu Hukum: Sebuah Deskripsi Tentang AsumsiAsumsi Dasar Teori Hukum Murni-Hans Kelsen. Jurnal Dinamika Hukum, 14(3), 369-383. 
Sholahuddin Al-Fatih

pp. 78-84
E-ISSN : 2723-2476

ISSN : 2723-1968

ACLJ, Vol. 1, Issue 2, 2020

https://doi.org/10.20884/1.jdh.2014.14.3.304

Worldometer. (2020). Covid-19 Pandemic (live).

Retrieved from

https://www.worldometers.info/coronavirus/

Zubaidi, N., Pratamab, G., \& Al-Fatih, S. (2020). Legal Perspective on Effectiveness of Pre-Work Cards for Indonesian People. Jurnal Bestuur, 8(1). https://doi.org/10.20961/bestuur.42722 